\title{
Bartonella vinsonii subsp. berkhoffii subsp. nov., Isolated from Dogs; Bartonella vinsonii subsp. vinsonii; and Emended Description of Bartonella vinsonii
}

\author{
DORSEY L. KORDICK, ${ }^{1}$ B. SWAMINATHAN, ${ }^{2}$ CRAIG E. GREENE, ${ }^{3}$ KENNETH H. WILSON, ${ }^{4,5}$ \\ ANNE M. WHITNEY, ${ }^{6}$ STEVE O'CONNOR, ${ }^{7}$ DANNIE G. HOLLIS, ${ }^{6}$ GHASSAN M. MATAR, ${ }^{2}$ \\ ARNOLD G. STEIGERWALT, ${ }^{6}$ GEORGIA B. MALCOLM ${ }^{2}{ }^{2}$ PEGGY S. HAYES, ${ }^{2}$ \\ TED L. HADFIELD, ${ }^{8}$ EDWARD B. BREITSCHWERDT, ${ }^{1}$ \\ AND DON J. BRENNER ${ }^{6 *}$
}

\begin{abstract}
Department of Companion Animal and Special Species Medicine, College of Veterinary Medicine, North Carolina State University, Raleigh, North Carolina 27606 ${ }^{1}$; Foodborne and Diarrheal Diseases Branch, ${ }^{2}$ Childhood and Vaccine Preventable Diseases Branch, ${ }^{6}$ and Emerging Bacterial and Mycotic Diseases Branch, ${ }^{7}$ Division of Bacterial and Mycotic Diseases, National Center for Infectious Diseases, Centers for Disease Control and Prevention, Atlanta, Georgia 30333; Department of Medical Microbiology, College of Veterinary Medicine, University of Georgia, Athens, Georgia 30602 ${ }^{3}$; Division of Infectious Diseases, Duke University Medical Center, ${ }^{4}$ and Veterans Affairs Medical Center, ${ }^{5}$ Durham, North Carolina 27710; and Department of Infectious and Parasitic Diseases Pathology, Armed Forces Institute of Pathology, Washington, D.C. $20306^{8}$
\end{abstract}

\begin{abstract}
Two bacterial strains, one isolated from the blood of a dog with valvular endocarditis and one isolated from the blood of a healthy dog, were similar to Bartonella species, as determined by a number of phenotypic criteria, including growth characteristics, biochemical reactions, and cell wall fatty acid composition. The results of $16 \mathrm{~S}$ rRNA gene sequence similarity studies confirmed that these strains are closely related and belong in the genus Bartonella and that Bartonella vinsonii is their closest relative (the 16S rRNA of isolate 93-C01 ${ }^{\mathrm{T}}$ [T $=$ type $^{\mathrm{T}}$ strain] was $99.37 \%$ identical to the $16 \mathrm{~S}$ rRNA of the type strain of $B$. vinsonii, the 16S rRNA of isolate G7464 was $99.61 \%$ identical to the 16S rRNA of the type strain, and the 16S rRNAs of the dog isolates were $99.77 \%$ identical to each other). The $16 \mathrm{~S}$ rRNAs of both strains contained a 12-base insertion that was not present in the 16S rRNA of the type strain of any Bartonella species. DNA relatedness tests revealed that these strains were related at the species level to the type strain of $B$. vinsonii. They were, however, significantly more closely related to each other than to $B$. vinsonii. On the basis of their unique $16 \mathrm{~S}$ rRNA sequence insertion, their preferentially high level of relatedness, and their similar origins (dogs), we believe that strains 93-C01 ${ }^{\mathrm{T}}$ and $\mathrm{G} 7464$ should be placed in a separate subspecies of $B$. vinsonii, for which we propose the name $B$. vinsonii subsp. berkhoffii subsp. nov. The type strain of $B$. vinsonii subsp. berkhoffii is strain 93-C01 (= ATCC 51672). The description of $B$. vinsonii is emended to accommodate the new subspecies, and $B$. vinsonii subsp. vinsonii is described.
\end{abstract}

The genus Bartonella (which includes species formerly classified in the genera Rochalimaea [5] and Grahamella [2]) contains 10 species, 4 of which have been implicated in human disease. Bartonella quintana is the etiologic agent of trench fever and has been implicated as a causative agent of endocarditis, bacillary angiomatosis, and bacillary peliosis $(23,25,30)$. Bartonella henselae is the primary etiologic agent of bacillary angiomatosis, bacillary peliosis, and cat scratch disease $(19,28$, $30,35)$. Bartonella elizabethae has been isolated from an endocarditis patient (7), and Bartonella bacilliformis is the agent of classical bartonellosis which manifests as a progressive anemia (Oroya fever) or as a cutaneous disease (verruga peruana) (34). Bartonella vinsonii was isolated from voles in Grosse Isle, Quebec Province, Canada, in the 1940s (1); only one strain of $B$. vinsonii has been available previously. Bartonella talpae and Bartonella peromysci, which are found in small feral mammals, were recently transferred to the genus Bartonella from the genus Grahamella (2). Bartonella grahamii, Bartonella taylorii, and Bartonella doshiae are recently described species that are also associated with various small feral mammals (2).

In this paper we describe two additional isolates of $B$. vinsonii, one (strain $93-\mathrm{C}^{\mathrm{T}}[\mathrm{T}=$ type strain $]$ ) obtained from a

\footnotetext{
* Corresponding author
}

dog with endocarditis and one (strain G7464) obtained from an apparently healthy dog. These isolates are related to $B$. vinsonii at the species level, but are sufficiently distinct from the type strain of $B$. vinsonii that they are placed in a distinct subspecies, for which the name $B$. vinsonii subsp. berkhoffii subsp. nov. is proposed.

\section{MATERIALS AND METHODS}

Strains. B. quintana ATCC VR- $358^{\mathrm{T}}$, B. vinsonii ATCC VR- $152^{\mathrm{T}}, B$. henselae ATCC $49882^{\mathrm{T}}$, B. elizabethae ATCC $49927^{\mathrm{T}}$, and B. bacilliformis ATCC $35685^{\mathrm{T}}$ have been described previously $(5,35)$. The two Bartonella strains obtained from dogs were isolated independently in different laboratories. The workers in each laboratory began preliminary characterization by performing a biochemical analysis, a 16S rRNA gene sequence analysis, a cellular fatty acid analysis, and a restriction fragment length polymorphism (RFLP) analysis. Later, DNA hybridization studies were performed with both strains to determine the degrees of relatedness of the two isolates and $B$. vinsonii, and the 16S rRNA sequences were compared. Dog 1 (the source of strain $93-\mathrm{C}^{\mathrm{T}} 1^{\mathrm{T}}\left[=\right.$ ATCC $\left.51672^{\mathrm{T}}\right]$ ) was a 3-year-old spayed Labrador retriever that was presented to the North Carolina State University Veterinary Teaching Hospital and was subsequently diagnosed with valvular endocarditis. Details of the case history of this dog have been reported elsewhere (3). Dog 2 (the source of strain G7464 [= ATCC 35685]) was a healthy Greyhound participating as a control blood donor in a Hemobartonella canis study at the University of Georgia College of Veterinary Medicine. No pathology was attributed to Bartonella infection in dog 2 .

Isolation method. Blood was collected aseptically by jugular venipuncture from $\operatorname{dog} 1$ and was cultured on Trypticase soy agar supplemented with $5 \%$ defibrinated rabbit blood (BBL Microbiology Systems, Becton Dickinson, Cockeysville, Md.) as described previously (3). Blood collected for culture from dog 2 
in an Isolator 1.5 Microbial Tube was mixed by inverting the tube four or five times to lyse the cells and was transported to the Centers for Disease Control and Prevention laboratory the next morning. The method of Welch et al. (35) was used for blood cultures. The contents of the Isolator 1.5 tube were vigorously vortexed for $10 \mathrm{~s}$, the blood was withdrawn from the tube with a syringe, and $0.35-\mathrm{ml}$ portions were dispensed onto Columbia agar (BBL Microbiology Systems) supplemented with $5 \%$ sheep blood and onto chocolate agar prepared from GC base (BBL Microbiology Systems). The resulting plates were streaked for isolation and incubated in a candle jar at $37^{\circ} \mathrm{C}$

Biochemical tests. A biochemical evaluation of isolate $93-\mathrm{C}^{2} 1^{\mathrm{T}}$ (from dog 1) was performed with 6-day-old cultures harvested from solid media as described previously $(3,16)$. Gram staining, flagellum staining, and biochemical tests were performed with isolate G7464 (from dog 2) as described previously (6). The inocula used for biochemical evaluations were obtained by growing both isolates in heart infusion agar supplemented with $5 \%$ rabbit blood (BBL Microbiology Systems) for 2 to 3 days at $35^{\circ} \mathrm{C}$ in a candle extinction jar. The motility of cells suspended in heart infusion broth was determined with a $100 \times$ oil immersion objective. Preformed enzyme tests were performed by using the RapID ANA II system as recommended by the manufacturer (Innovative Diagnostic Systems, Inc., Norcross, Ga.).

Cellular fatty acid analysis. The Bartonella isolates obtained from the two dogs were grown on rabbit blood agar at $35^{\circ} \mathrm{C}$ for 10 days. The cells were saponified, and the liberated fatty acids were methylated and analyzed by capillary gas-liquid chromatography (Microbial ID, Inc., Newark, Del.) (22).

Electron microscopy. Transmission electron microscopy was used to compare the morphological features of $B$. henselae found in aortic valve tissue with the morphological features of the plate-grown blood isolate obtained from dog 1 (3, 5).

Extraction of Bartonella DNA for PCR amplification. Bacterial DNAs were extracted from isolate $93-\mathrm{C} 01^{\mathrm{T}}$ and aortic valve tissue obtained from dog 1 by a phenol-chloroform technique, as described previously (3). Bartonella DNA was extracted from the blood of $\operatorname{dog} 2$ by a modification of the procedure developed by Kim (15) to extract Listeria DNA from paraffin-embedded tissues. A $100-\mu 1$ portion of dog blood was centrifuged at $15,600 \times g$ for $10 \mathrm{~min}$, and the supernatant was discarded. The pellet was washed twice with $500 \mu l$ of TE $(0.01 \mathrm{M}$ Tris, $0.001 \mathrm{M}$ EDTA; pH 8.0) and suspended in $100 \mu \mathrm{l}$ of 5 mM EDTA (pH 8.0); $100 \mu$ l of lysozyme $(50 \mathrm{mg} / \mathrm{ml})$ was added, and the mixture was incubated at $37^{\circ} \mathrm{C}$ for $30 \mathrm{~min}$. Then $50 \mu \mathrm{l}$ of $20 \%$ sodium dodecyl sulfate was added, and, after mixing, the preparation was incubated for $10 \mathrm{~min}$ at $55^{\circ} \mathrm{C}$ to lyse the cells and release the DNA. Then $250 \mu \mathrm{l}$ microliters of endotoxin-free water was added to the lysate. The lysate was extracted once with phenol and once with chloroform. The aqueous phase was removed and placed in a new tube, and $1 \mu \mathrm{I}$ of an oyster glycogen solution $(20 \mathrm{mg} / \mathrm{ml}$; Sigma Chemical Co., St. Louis, Mo.) was added. The DNA was precipitated by adding 0.1 volume of $3 \mathrm{M}$ acetate and 0.6 volume of isopropanol and was pelleted by centrifugation at $12,000 \times g$ for $15 \mathrm{~min}$. The precipitated DNA was washed once with $70 \%$ ethanol, dried, and resuspended in $80 \mu \mathrm{l}$ of endotoxin-free water. Template DNA for PCR amplification was obtained from cultures of isolate G7464 by the method of Heller et al. (12).

PCR amplification of a fragment of the gene coding for 16S rRNA. DNAs obtained from blood culture isolate $93-\mathrm{C} 1^{\mathrm{T}}$ and aortic valve tissue from dog 1 were amplified by PCR by using a previously described method (3). The PCR in which DNA from the blood of dog 2 was used was performed essentially as described by Relman et al. (20) by using Bartonella-specific primers p12B and $\mathrm{p} 24 \mathrm{E}$ and universal eubacterial primers $\mathrm{p} 11 \mathrm{E}$ and p13B. A positive control (paraffin-embedded tissue prepared from tissue that had been artificially inoculated with $B$. henselae) and a negative control (endotoxin-free water extracted by the procedure that was used for the clinical specimens) were included in each set of reactions to monitor the efficacy of extraction and to check for cross-contamination of specimens during extraction. A reagent cocktail control (containing all of the components of the PCR mixture except target DNA) was included to check for contamination during PCR setup. A positive control (Bartonella DNA) was included to verify that amplification of the desired PCR product occurred. The PCR product (length, $282 \mathrm{bp}$ ) was detected by electrophoresis on a $1.5 \%$ agarose-1.0\% NuSieve agarose (FMC, Rockland, Maine) gel in $1 \times$ Tris-borate buffer at $100 \mathrm{~V}$ for $1.25 \mathrm{~h}$, followed by ethidium bromide staining of the gel.

PCR-RFLP subtyping. The spacer region between the genes coding for $16 \mathrm{~S}$ and $23 \mathrm{~S}$ rRNAs was amplified by PCR by using the procedure of Matar et al. (17).

DNA hybridization methods. Strains were grown on heart infusion agar supplemented with rabbit blood at $35^{\circ} \mathrm{C}$ for 3 to 4 days. The DNA extraction and purification procedures and the hydroxyapatite hybridization method which we used have been described previously (4). The level of divergence of related sequences was estimated to be approximately $1 \%$ for each $1^{\circ} \mathrm{C}$ decrease in the thermal stability of a heterologous reassociated DNA duplex compared with the thermal stability of the homologous reassociated DNA duplex (4). Levels of divergence were calculated to the nearest $0.5 \%$. DNA was labeled enzymatically in vitro with $\left[\alpha-{ }^{32} \mathrm{P}\right] \mathrm{dCTP}$ by using a nick translation kit (Gibco BRL, Gaithersburg, Md.).

PCR amplification of the gene coding for $16 \mathrm{~S}$ rRNA and sequencing of the amplified product. PCR amplification of the 16S rRNA gene from $93-\mathrm{C01} 1^{\mathrm{T}}$ and the subsequent sequence reaction experiments were performed with a model Gene-Amp 9600 thermal cycler (Perkin-Elmer Cetus, Norwalk, Conn.) by using a previously described protocol (3). The template DNA used for direct sequencing of isolate G7464 was produced by enzymatic amplification of the 16S rRNA gene, using primers $\mathrm{fD} 1$ and $\mathrm{rD1}$, as described by Weisburg et al. (31), and methods described by Daly et al. (7). PCR products were purified by using Dynabead M280 streptavidin-coated magnetic beads (Dynal, Inc., Great Neck, N.Y.) and the modification of the method of Hultman et al. (13) described previously (7). Ten oligonucleotides described by Stackebrandt and Charfreitag (27) were used as sequencing primers for the eluted strand, and reverse complementary oligonucleotides to these 10 oligonucleotides were used to sequence the bound strand.

$16 S$ rRNA sequence analysis. All of the 16S rRNA sequences used in this study were retrieved electronically from the GenBank database $(5,8)$. In the case of 93-C $01^{\mathbf{T}}$ sequence alignment was performed by using the Genetic Data Environment (24) and a Sun Sparcstation II (Sun Microsystems, Mountain View, Calif.). Sequence data for $\mathrm{G} 7464$ were aligned by using the multisequence alignment program PILEUP, which is part of the Genetics Computer Group (Madison, Wis.) software package (8). The alignment was masked to remove variable regions where the nucleotide alignment could not be reliably determined. Phylogenetic relationships were inferred from the data by using version $3.5 \mathrm{c}$ of the PHYLIP software package (10). Evolutionary distance values determined by the method of Jukes and Cantor (14) were used to calculate rRNA similarity values and to construct a dendrogram by the neighbor-joining method (21). The reliability of the tree was analyzed by bootstrapping the data (9).

Nucleotide sequence accession numbers. The 16S rRNA gene sequence of strain $93-\mathrm{C}_{01}{ }^{\mathrm{T}}$ has been deposited in the GenBank, EMBL, and DDBJ databases under accession number L35052. The 16S rRNA sequence of strain G7464 has been deposited in the GenBank database under accession number U26258.

\section{RESULTS}

While researchers were attempting to isolate Hemobartonella species from cats and dogs in 1992, an organism that resembled Bartonella species was isolated serendipitously from an apparently healthy greyhound ( $\operatorname{dog} 2)$ whose blood was used as a negative control. This dog was retired from racing and was used as a chronic blood donor in the Small Animal Clinic at the School of Veterinary Medicine at the University of Georgia. Dog 2 had no clinical abnormalities other than lacerations resulting from a dog fight.

In 1993, dog 1 was presented to the Veterinary Teaching Hospital at the North Carolina State University College of Veterinary Medicine in Raleigh, and endocarditis involving the mitral and aortic valves was diagnosed. The use of conventional blood culture techniques failed to result in bacterial growth; however, the results of lysis centrifugation cultures demonstrated that Bartonella bacteremia occurred.

Isolation of microorganisms. The isolate obtained from dog 1 (strain 93-C $01^{\mathrm{T}}$ ) appeared following 8 days of incubation at $35^{\circ} \mathrm{C}$ in the presence of $5 \% \mathrm{CO}_{2}$ on Trypticase soy agar supplemented with $5 \%$ rabbit blood. Subcultures grew vigorously within 4 days. The isolate obtained from dog 2 (strain G7464) grew as a pure culture on Columbia agar supplemented with $5 \%$ sheep blood after 4 days of incubation at $37^{\circ} \mathrm{C}$ in a candle jar. Strain G7464 was very fastidious and grew best when it was subcultured on chocolate agar and incubated at $35^{\circ} \mathrm{C}$ in the presence of 5 to $10 \% \mathrm{CO}_{2}$. It did not grow at $42^{\circ} \mathrm{C}$ or anaerobically.

Microscopic, biochemical, and cellular fatty acid analysis. Gram staining of both isolates revealed short, slender, faintly staining, gram-negative bacilli that often occurred in masses. No motility or flagella were detected. Tests for catalase activity, urease activity, acid production from D-glucose, lactose, maltose, D-mannitol, D-xylose, and sucrose, and nitrate reduction and spot indole tests were negative. When the Rapid ANA II system was used, we observed hydrolysis of leucylglycine, glycine, proline (weak), phenylalanine, arginine, and serine. The phenotypic characteristics of strains $93-\mathrm{C}^{\mathrm{T}} 1^{\mathrm{T}}$ and $\mathrm{G} 7464$ were compared with those of five other Bartonella species (Table 1). All of the strains grew on heart infusion agar supplemented with rabbit blood. Other than hydrolysis of the same nine substrates (when they were tested), there were few other 
TABLE 1. Biochemical characteristics of bartonellae

\begin{tabular}{|c|c|c|c|c|c|c|c|}
\hline Characteristic & 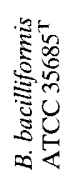 & 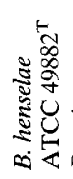 & 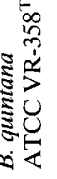 & 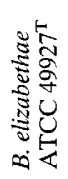 & 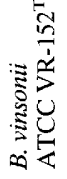 & 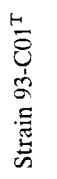 & 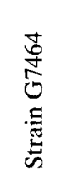 \\
\hline Oxidase activity & $-a$ & - & $\mathrm{v}$ & - & $-b$ & $\mathrm{v}$ & \\
\hline \multicolumn{8}{|l|}{ Peptidase activities } \\
\hline Alanine & ND & + & + & + & ND & + & ND \\
\hline A & + & + & + & + & + & + & + \\
\hline $\mathrm{Gl}$ & + & + & + & + & + & + & $r$ \\
\hline His & ND & + & + & + & ND & + & ND \\
\hline Leuc & ND & + & + & + & ND & + & NI \\
\hline Leucylglycine & ND & + & + & + & + & + & + \\
\hline Phenylalar & + & + & + & + & + & + & + \\
\hline Prol & $+{ }^{w}$ & + & + & + & + & + & \\
\hline Seri & ND & + & + & + & + & + & $\mathrm{NI}$ \\
\hline Tyro & ND & $\mathrm{v}$ & - & + & ND & + & $\mathrm{NI}$ \\
\hline Valine & ND & + & $t^{\mathrm{w}}$ & - & ND & + & $\mathrm{N}$ \\
\hline Esterase activ & ND & - & - & - & ND & $t^{\mathrm{w}}$ & ND \\
\hline Phosphohydrolase ac & ND & + & $\mathrm{v}$ & $+{ }^{w}$ & ND & $+{ }^{w}$ & ND \\
\hline Trypsin activity & ND & + & - & - & ND & $\mathrm{v}$ & $\mathrm{ND}$ \\
\hline
\end{tabular}

$a_{-}$, negative reaction after 7 days; + , positive reaction within $48 \mathrm{~h} ;+^{\mathrm{w}}$, weak positive reaction; v, variable; ND, not done.

${ }^{b}$ Negative as determined by the routine oxidase test and weakly positive as determined by the oxidase test performed with the Kovacs reagent.

positive characteristics. $B$. quintana and $B$. vinsonii were weakly oxidase positive (Kovacs); B. quintana, B. vinsonii, B. elizabethae, and some strains of $B$. henselae grew on heart infusion agar containing $\mathrm{X}$ factors; and $B$. elizabethae produced incomplete hemolysis. Only $B$. bacilliformis was motile and grew better at $25^{\circ} \mathrm{C}$ than at $35^{\circ} \mathrm{C}$.

The results of our cellular fatty acid analysis confirmed that the type strain of $B$. vinsonii (strain ATCC VR-152) and dog strains $93-\mathrm{C}^{\mathrm{T}} \mathrm{T}^{\mathrm{T}}$ and $\mathrm{G} 7464$ had profiles that in general were similar to those of Bartonella species. These results suggested, however, that the cellular fatty acid profile of G7464 was more similar to the profile of the $B$. vinsonii type strain than to the strain $93-\mathrm{C}^{\mathrm{T}} 1^{\mathrm{T}}$ profile.

Transmission electron microscopy revealed that the dog 1 isolate and bacilli found in the aortic valve were similar in size and morphology. However, a thinner glycocalyx layer was observed in the cultured organism.

PCR-RFLP analysis. DNA fragments of the expected sizes were amplified from dog blood when we used both the universal 16S rRNA primers and the Bartonella-specific primers, indicating that Bartonella ribosomal DNA was present in the dog blood. When the ribosomal intergenic spacer region was subtyped by the PCR-RFLP technique by using HaeIII to restrict the PCR-amplified fragment, the pattern obtained was very different from the pattern obtained for the type strain of $B$. vinsonii and similar, but not identical, to one of the patterns obtained for B. henselae (Fig. 1).

rRNA gene sequence analysis. The partial $16 \mathrm{~S}$ rRNA gene sequences of both dog isolates were compared with each other and with the sequences of other Bartonella species obtained from the GenBank database. A total of 1,446 nucleotide positions were determined for the dog 1 isolate, and 1,478 positions were determined for the dog 2 isolate. The sequence data obtained for both dog isolates were most similar to the $B$. vinsonii data (levels of similarity to $93-\mathrm{C} 01^{\mathrm{T}}$ and $\mathrm{G} 7464,99.37$ and $99.61 \%$, respectively). The level of $16 \mathrm{~S}$ rRNA similarity between the dog isolates was $99.77 \%$ (Table 2). Figure 2 is a dendrogram which shows the relationships of the dog strains to
Bartonella species and to other closely related species. This dendrogram is the majority rule consensus tree based on 100 trees constructed from bootstrapped data. The bootstrap value (calculated from the number of times out of 100 trees that the species or isolates grouped together) for the group containing the eight Bartonella species and the two dog isolates was $100 \%$.

A unique insertion sequence (5' CAGGGAGACCTT 3') involving the first stem and loop of the variable V2 region between corresponding Escherichia coli positions 183 and 188 was identified in both canine isolates. No other Bartonella species or other microorganism in the version of the Ribosomal Database Project data which we used had as long an insertion at this point.

DNA hybridization studies. DNA relatedness studies were performed by using labeled DNAs from both dog Bartonella isolates and from the type strain of $B$. vinsonii (Table 3 ). The two dog strains were $91 \%$ related with $0.5 \%$ divergence in optimal DNA reassociation reactions at $55^{\circ} \mathrm{C}$. They were $93 \%$ related in stringent DNA reassociation reactions at $70^{\circ} \mathrm{C}$. These strains exhibited average levels of relatedness to the type strain of $B$. vinsonii of $82 \%$ with $4.3 \%$ divergence at $55^{\circ} \mathrm{C}$ and $70 \%$ at $70^{\circ} \mathrm{C}$. In reciprocal reactions, labeled DNA from the $B$. vinsonii type strain exhibited average levels of relatedness to the dog Bartonella isolates of $75 \%$ with $4.8 \%$ divergence at $55^{\circ} \mathrm{C}$ and $63 \%$ at $70^{\circ} \mathrm{C}$. The levels of relatedness of the dog Bartonella strains and the type strain of $B$. vinsonii to other Bartonella species in reactions at $55^{\circ} \mathrm{C}$ ranged from 26 to $68 \%$ with 9 to $13 \%$ divergence.

\section{DISCUSSION}

Rochalimaea vinsonii was isolated from voles during the 1940s by James Baker, Veterinary Corps, U.S. Army, while he was stationed at the War Disease Control Station at Grosse Isle, Quebec Province, Canada (1). During autopsies of several captured voles, Baker noticed that some of the animals had enlarged spleens. He observed coccoid and bacillary forms in stained tissues from voles with normal and enlarged spleens, but was unable to culture any organism in or on bacteriologic media. Because Grosse Isle was used as a quarantine station for immigrants in the 19th century and several Irish immigrants that reached the island had died of typhus and were buried there, Baker suspected that the vole organisms could be rick-

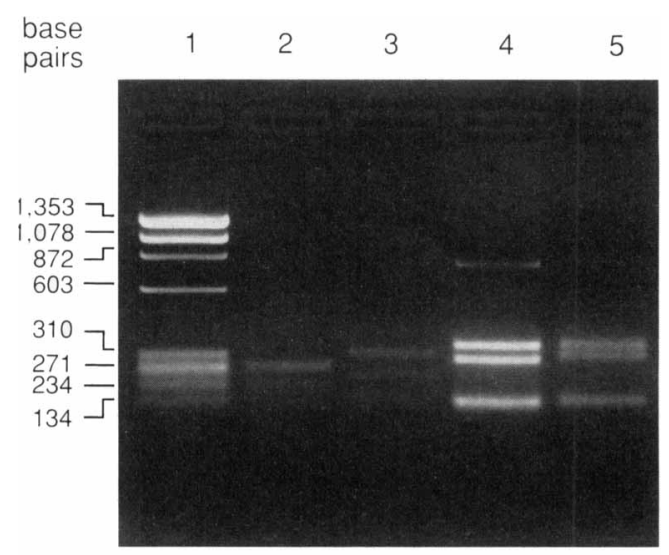

FIG. 1. PCR-RFLP patterns of dog isolate G7467 and type strains of Bartonella species obtained by restriction with restriction endonuclease HaeIII. Lane 1 , size marker ( $\phi$ X174 DNA restricted with HaeIII); lane 2, B. quintana ATCC VR- $358^{\mathrm{T}}$; lane 3, B. vinsonii ATCC VR- $152^{\mathrm{T}}$; lane $4, B$. henselae ATCC $49882^{\mathrm{T}}$; lane 5, dog isolate G7467. 
TABLE 2. $16 \mathrm{~S}$ ribosomal DNA similarity values obtained from a multiple-sequence alignment of 1,327 nucleotides

\begin{tabular}{|c|c|c|c|c|c|c|c|c|c|c|c|}
\hline \multirow[b]{2}{*}{ Organism } & \multicolumn{11}{|c|}{$\% 16 \mathrm{~S}$ ribosomal DNA similarity ${ }^{a}$} \\
\hline & $\begin{array}{c}\text { Dog } \\
\text { isolate } \\
\text { G7464 }\end{array}$ & $\begin{array}{c}\text { Dog } \\
\text { isolate } \\
\text { 93-C01 }\end{array}$ & $\begin{array}{c}\text { Bartonella } \\
\text { vinsonii } \\
\text { ATCC } \\
\text { VR-152 }\end{array}$ & $\begin{array}{c}\text { Bartonella } \\
\text { henselae } \\
\text { ATCC } \\
49882^{\mathrm{T}}\end{array}$ & $\begin{array}{c}\text { Bartonella } \\
\text { quintana } \\
\text { ATCC } \\
\text { VR- } 358^{\mathrm{T}}\end{array}$ & $\begin{array}{c}\text { Bartonella } \\
\text { elizabethae } \\
\text { ATCC } \\
49927^{\mathrm{T}}\end{array}$ & $\begin{array}{c}\text { Bartonella } \\
\text { bacilliformis } \\
\text { ATCC } \\
35685^{\mathrm{T}}\end{array}$ & $\begin{array}{c}\text { Brucella } \\
\text { abortus }\end{array}$ & $\begin{array}{l}\text { Agrobacterium } \\
\text { tumefaciens }\end{array}$ & $\begin{array}{l}\text { Ehrlichia } \\
\text { sennetsu }\end{array}$ & $\begin{array}{l}\text { Anacystis } \\
\text { nidulans }\end{array}$ \\
\hline Dog isolate G7464 & 100 & & & & & & & & & & \\
\hline Dog isolate $93-\mathrm{C}^{2} 1^{\mathrm{T}}$ & 99.77 & 100 & & & & & & & & & \\
\hline $\begin{array}{l}\text { Bartonella vinsonii ATCC } \\
\text { VR- } 152^{\mathrm{T}}\end{array}$ & 99.61 & 99.37 & 100 & & & & & & & & \\
\hline $\begin{array}{l}\text { Bartonella henselae ATCC } \\
49882^{\mathrm{T}}\end{array}$ & 99.21 & 98.98 & 99.45 & 100 & & & & & & & \\
\hline $\begin{array}{l}\text { Bartonella quintana } \\
\text { ATCC VR-358 }\end{array}$ & 98.99 & 98.75 & 98.83 & 98.98 & 100 & & & & & & \\
\hline $\begin{array}{l}\text { Bartonella elizabethae } \\
\quad \text { ATCC } 49927^{\mathrm{T}}\end{array}$ & 99.29 & 99.21 & 99.21 & 98.90 & 98.67 & 100 & & & & & \\
\hline $\begin{array}{l}\text { Bartonella bacilliformis } \\
\text { ATCC } 35685^{\mathrm{T}}\end{array}$ & 98.28 & 98.04 & 98.44 & 98.36 & 98.12 & 98.44 & 100 & & & & \\
\hline Brucella abortus & 95.83 & 95.67 & 95.75 & 95.20 & 95.13 & 95.75 & 95.05 & 100 & & & \\
\hline Agrobacterium tumefaciens & 94.20 & 94.43 & 94.27 & 93.88 & 93.57 & 94.27 & 93.73 & 93.71 & 100 & & \\
\hline Ehrlichia sennetsu & 81.85 & 81.99 & 81.92 & 81.84 & 81.60 & 81.92 & 81.60 & 82.34 & 82.32 & 100 & \\
\hline Anacystis nidulans & 76.02 & 76.15 & 76.58 & 76.65 & 76.76 & 76.58 & 77.13 & 76.90 & 76.42 & 74.37 & 100 \\
\hline
\end{tabular}

${ }^{a}$ The values were corrected for multiple base changes by the method of Jukes and Cantor (14).

ettsiae. He started culturing the organisms in the yolk sacs of developing eggs.

Weiss et al. (33) initially characterized the Baker isolate (strain VR-152) as a strain of Rochalimaea quintana, but later classified the organism as a new species, $R$. vinsonii, on the basis of the results of DNA-DNA hybridization tests (32). We are not aware of other isolates of $R$. vinsonii obtained after Baker's original isolates, and this organism has not been associated with any human or animal disease.

In this study we compared two Bartonella isolates, one obtained from a presumably healthy dog and one obtained from a dog with endocarditis. The biochemical profiles of both isolates were consistent with the profiles observed for Bartonella species. Conventional biochemical tests, however, cannot be used dependably for differentiation of Bartonella species because of the inert nature and growth requirements of these organisms. Similarly, cellular fatty acid analysis can be used to determine identity at the genus level, but cannot be used to reliably distinguish among the species.

RFLP analyses of PCR-amplified ribosomal DNA intergenic spacer regions have been shown to be useful for intraspecies subtyping of $B$. henselae and $B$. quintana $(17,26)$. The two dog isolates could not be distinguished from each other when they were analyzed by using the PCR-RFLP procedure with AluI and HaeIII for restriction of the amplified DNAs, but their profiles were completely different from the profile of the type strain of $B$. vinsonii. In contrast, the restriction patterns of the two dog isolates were very similar to the restriction pattern of the type strain of $B$. henselae (they differed by a single band). As additional dog isolates are obtained, it will be interesting to determine if the PCR-RFLP method can be used for strain differentiation.

The 16S rRNA gene sequences of the two dog isolates were almost identical, which is consistent with placement of these organisms in the same species. The results of our 16S rRNA gene sequence analysis confirmed that the dog strains are members of the genus Bartonella and that their closest relative is $B$. vinsonii. Our $16 \mathrm{~S}$ rRNA sequence analysis also revealed that the two dog strains contain the same 12-base insertion, the microbiological significance of which is unknown.

DNA hybridization has been recommended in preference to
16S rRNA gene sequencing as the method of choice for differentiating species $(11,18,29)$. The recommended phylogenetic definition of a species is a group of "strains with approximately $70 \%$ or greater DNA-DNA relatedness and with $5^{\circ} \mathrm{C}$ or less delta $T_{m}$. Both values must be considered" (29) (delta $T_{m}$ is the difference between the melting temperature of a homologous hybrid and the melting temperature of a heterologous hybrid); $1{ }^{\circ} \mathrm{C}$ of delta $T_{m}$ is approximately equivalent to $1 \%$ divergence. It has also been demonstrated that the subspecies concept is phylogenetically valid, on the basis of the frequency distribution of levels of divergence within related sequences and preferentially high levels of intraspecies relatedness (29).

The results of the DNA relatedness tests showed that the two dog isolates were members of the same species and that both of these strains were related to the type (and only available) strain of $B$. vinsonii at the species level. The levels of relatedness between the dog isolates, however, were substantially higher $\left(91 \%\right.$ with $0.5 \%$ divergence at $55^{\circ} \mathrm{C} ; 93 \%$ at $\left.70^{\circ} \mathrm{C}\right)$ than the levels of relatedness between either dog strain and the type strain of $B$. vinsonii (the average values in reciprocal reactions were $78 \%$ with $4.5 \%$ divergence at $55^{\circ} \mathrm{C}$ and $67 \%$ at $70^{\circ} \mathrm{C}$ ). The levels of relatedness of the $\operatorname{dog}$ isolates to $B$. gra-

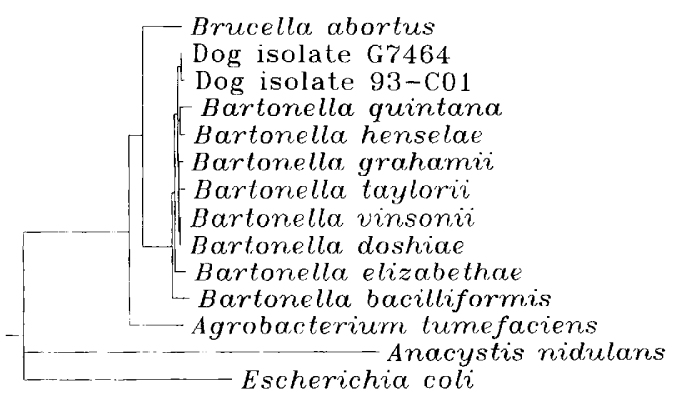

FIG. 2. Phylogenetic dendrogram based on an alignment of 1,327 nucleotides of the 16S ribosomal DNAs of organisms belonging to the alpha subdivision of the Proteobacteria. Escherichia coli and Anacystis nidulans were included as outgroups. Scale bar $=5 \%$ nucleotide difference. 
TABLE 3. Levels of DNA relatedness for Bartonella dog isolates and other bartonellae

\begin{tabular}{|c|c|c|c|c|c|c|c|c|c|}
\hline \multirow[b]{3}{*}{ Source of unlabeled DNA } & \multicolumn{9}{|c|}{ Source of labeled DNA } \\
\hline & \multicolumn{3}{|c|}{ Bartonella sp. strain G7464 } & \multicolumn{3}{|c|}{ Bartonella sp. strain $93-\mathrm{C}^{2} 1^{\mathrm{T}}$} & \multicolumn{3}{|c|}{ B. vinsonii ATCC VR- $152^{\mathrm{T}}$} \\
\hline & 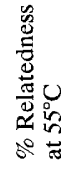 & 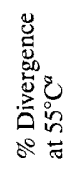 & 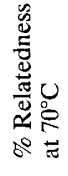 & 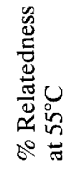 & 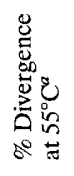 & 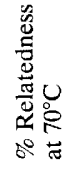 & 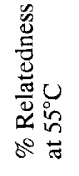 & 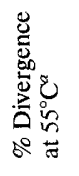 & 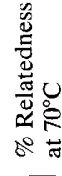 \\
\hline Bartonella sp. strain G7464 & 100 & 0.0 & 100 & $\mathrm{ND}^{b}$ & ND & ND & 77 & 5.0 & 59 \\
\hline Bartonella sp. strain $93-\mathrm{C} 01^{\mathrm{T}}$ & 91 & 0.5 & 94 & 100 & 0.0 & 100 & 72 & 4.5 & 67 \\
\hline B. vinsonii ATCC VR- $152^{\mathrm{T}}$ & 82 & 3.5 & 70 & 81 & 5.0 & 70 & 100 & 0.0 & 100 \\
\hline B. henselae G5436 & 68 & 9.0 & 38 & ND & ND & ND & ND & ND & ND \\
\hline B. henselae G1061 & 64 & 12.0 & 29 & ND & ND & ND & ND & ND & ND \\
\hline B. henselae ATCC $49882^{\mathrm{T}}$ & 62 & 10.0 & 39 & 55 & 10.5 & ND & 55 & 11.0 & 16 \\
\hline B. henselae G5829 & 62 & 11.0 & 30 & ND & ND & ND & ND & ND & ND \\
\hline B. henselae G1054 & 58 & 12.0 & 20 & ND & ND & ND & ND & ND & $\mathrm{ND}$ \\
\hline B. quintana ATCC VR- $358^{\mathrm{T}}$ & 58 & 10.0 & 31 & 47 & 10.5 & ND & 49 & 10.0 & 20 \\
\hline B. elizabethae ATCC $49927^{\mathrm{T}}$ & 57 & 12.0 & 26 & 52 & 13.0 & ND & 54 & 12.5 & 17 \\
\hline B. bacilliformis ATCC $35685^{\mathrm{T}}$ & 26 & 11.0 & $\mathrm{ND}$ & 33 & 13.0 & ND & 33 & 10.5 & ND \\
\hline
\end{tabular}

${ }^{a}$ Level of divergence for related sequences, calculated to the nearest $0.5 \%$.

${ }^{b}$ ND, not done.

hamii, B. taylorii, and B. doshiae were not determined since the type strains of these recently described species were not available. Birtles et al. showed previously that these species were less than $40 \%$ related to $B$. vinsonii (2). B. talpae and $B$. peromysci were not tested as there are no known strains of these species (2). In view of these results, there seems to be no doubt that the dog isolates are $B$. vinsonii isolates and are the first isolates of this organism obtained in almost 50 years and the first isolates obtained from dogs; in addition, isolate $93-\mathrm{C}^{\mathrm{T}}{ }^{\mathrm{T}}$ is the first member of this species that has been shown to be responsible for a disease. The dog isolates of $B$. vinsonii can be differentiated from the $B$. vinsonii type strain on the basis of their preferentially high levels of DNA relatedness and low levels of divergence in related sequences, by the presence of a unique insertion in their $16 \mathrm{~S}$ rRNAs, by their different RFLP pattern, by their different source of isolation, and by their pathogenicity. Therefore, we feel that we are justified in creating a new subspecies for these organisms as proposed and described below.

Emendation of the description of Bartonella vinsonii. Bartonella vinsonii (Brenner, O'Connor, Winkler, and Steigerwalt 1993 [5]) (basonym, Rochalimaea vinsonii Weiss and Dasch 1982 [32]). The characteristics of this taxon are the same as those described for the genus (5) and those described by Weiss and Moulder for the species (34). Additional biochemical characteristics are shown in Table 1.

The species contains two subspecies, one of which has been isolated only from voles and one of which has been isolated only from dogs, including a dog with a case of canine endocarditis.

Description of Bartonella vinsonii subsp. vinsonii subsp. nov. B. vinsonii subsp. vinsonii (vin.so'ni.i. N. L. gen. n. vinsonii, of Vinson, in honor of J. William Vinson who, along with Henry S. Fuller, first demonstrated that Bartonella [formerly Rochalimaea] quintana could be grown on blood agar). The characteristics are the same as those of the species. Weakly oxidase positive as determined by the Kovacs method. Grows on heart infusion agar supplemented with $\mathrm{X}$ factor.

The type and only strain is strain ATCC VR-152, which was isolated from voles by Baker in 1946 (1). The nucleotide sequence of the 16S rRNA gene of the type strain has been deposited in the GenBank database under accession number M73230 (19).
Description of Bartonella vinsonii subsp. berkhoffii subsp. nov. B. vinsonii subsp. berkhoffii (berk.hof'fi.i. N. L. gen. n. berkhoffi, of Berkhoff, in honor of Herman A. Berkhoff, a veterinary microbiologist whose research encompasses a wide spectrum of veterinary pathogens, and who contributed to the study of Bartonella infection in domestic animals that led to the recognition of this subspecies). The characteristics are the same as those of the species. Oxidase negative as determined by the Kovacs method. Does not grow on heart infusion agar supplemented with $\mathrm{X}$ factor. Can be differentiated from $B$. vinsonii subsp. vinsonii by its RFLP pattern, by DNA hybridization values, and by the presence of a 12-base insertion in the $\mathrm{V} 2$ region of its $16 \mathrm{~S}$ rRNA gene.

Isolated from a dog with endocarditis and a cause of this disease in dogs.

The type strain is strain 93-C01 (= ATCC 51672), which was isolated from a dog with endocarditis. The nucleotide sequence of the 16S rRNA gene of the type strain has been deposited in the GenBank database under accession number L35052.

\section{ACKNOWLEDGMENTS}

We gratefully acknowledge Leonard W. Mayer for consulting on $16 \mathrm{~S}$ rRNA sequences and Hal Hills, Jenny Simchock, Rhonda Blitchington, and Patty Davidson for excellent technical assistance.

This study was supported by the State of North Carolina and the Department of Veterans Affairs.

\section{REFERENCES}

1. Baker, J. A. 1946. A rickettsial infection in Canadian voles. J. Exp. Med. 84:37-51.

2. Birtles, R. J., T. G. Harrison, N. S. Saunders, and D. H. Molyneux. 1995. Proposals to unify the genera Grahamella and Bartonella, with descriptions of Bartonella talpae comb. nov., Bartonella peromysci comb. nov., and three new species, Bartonella grahamii sp. nov., Bartonella taylorii sp. nov., and Bartonella doshiae sp. nov. Int. J. Syst. Bacteriol. 45:1-8.

3. Breitschwerdt, E. B., D. L. Kordick, D. E. Malarkey, B. Keene, T. L. Hadfield, and K. Wilson. 1995. Endocarditis in a dog due to infection with a novel Bartonella subspecies. J. Clin. Microbiol. 33:154-160.

4. Brenner, D. J., A. C. McWhorter, J. K. Leete Knutson, and A. G. Steigerwalt. 1982. Escherichia vulneris: a new species of Enterobacteriaceae associated with human wounds. J. Clin. Microbiol. 15:1133-1140.

5. Brenner, D. J., S. P. O'Connor, H. H. Winkler, and A. G. Steigerwalt. 1993. Proposals to unify the genera Bartonella and Rochalimaea, with descriptions of Bartonella quintana comb. nov., Bartonella vinsonii comb. nov., Bartonella henselae comb. nov., and Bartonella elizabethae comb. nov., and to remove 
the family Bartonellaceae from the order Rickettsiales. Int. J. Syst. Bacteriol. 43:777-786.

6. Clark, W. A., D. G. Hollis, R. E. Weaver, and P. Riley. 1984. Identification of unusual pathogenic gram-negative aerobic and facultatively anaerobic bacteria. Centers for Disease Control, Atlanta.

7. Daly, J. S., M. G. Worthington, D. J. Brenner, C. W. Moss, D. G. Hollis, R. S. Weyant, A. G. Steigerwalt, R. E. Weaver, M. I. Daneshvar, and S. P. O'Connor. 1993. Rochalimaea elizabethae sp. nov. isolated from a patient with endocarditis. J. Clin. Microbiol. 31:872-881.

8. Devereux, J., P. Haeberli, and O. Smithies. 1984. A comprehensive set of sequence analysis programs for the VAX. Nucleic Acids Res. 12:387-395.

9. Felsenstein, J. 1985. Confidence limits on phylogenies. An approach using the bootstrap. Evolution 39:783-791.

10. Felsenstein, J. 1989. PHYLIP-phylogeny inference package (version 3.2). Cladistics 5:164-166.

11. Fox, G. E., J. D. Wisotzkey, and P. Jurtshuk, Jr. 1992. How close is close: 16 S rRNA sequence identity may not be sufficient to guarantee species identity. Int. J. Syst. Bacteriol. 42:166-170.

12. Heller, M. J., L. J. Burgart, C. J. TenEyck, M. E. Anderson, T. C. Greiner, and R. A. Robinson. 1991. An efficient method for the extraction of DNA from formalin-fixed, paraffin-embedded tissue by sonication. BioTechniques 11:372-377.

13. Hultman, T., S. Stahl, E. Hornes, and M. Uhlen. 1989. Direct solid phase sequencing of genomic and plasmid DNA using magnetic beads as solid support. Nucleic Acids Res. 17:4937-4946.

14. Jukes, T. H., and C. R. Cantor. 1969. Evolution of protein molecules, p. 21-132. In H. N. Munro (ed.), Mammalian protein metabolism, vol. 3. Academic Press, Inc., New York.

15. Kim, C. L. M. Graves, B. Swaminathan, L. W. Mayer, and R. E. Weaver. 1991. Evaluation of hybridization characteristics of a cloned pRF106 probe for Listeria monocytogenes detection and development of a nonisotopic colony hybridization assay. Appl. Environ. Microbiol. 57:289-294.

16. MacFaddin, J. F. 1980 . Biochemical tests for identification of medical bacteria. The Williams and Wilkins Co., Baltimore.

17. Matar, G. M., B. Swaminathan, S. B. Hunter, L. N. Slater, and D. F. Welch. 1993. Polymerase chain reaction-based restriction fragment length polymorphism analysis of a fragment of the ribosomal operon from Rochalimaea species for subtyping. J. Clin. Microbiol. 31:1730-1734.

18. Murray, R. G. E., D. J. Brenner, R. R. Colwell, P. De Vos, M. Goodfellow, P. A. D. Grimont, N. Pfennig, E. Stackebrandt, and G. A. Zaverzin. 1990. Report of the Ad Hoc Committee on Approaches to Taxonomy within the Proteobacteria. Int. J. Syst. Bacteriol. 40:213-215.

19. Regnery, R. L., B. E. Anderson, J. E. Clarridge III, M. C. RodriguezBarradas, D. C. Jones, and J. H. Carr. 1992. Characterization of a novel Rochalimaea species, $R$. henselae sp. nov., isolated from blood of a febrile, human immunodeficiency virus-positive patient. J. Clin. Microbiol. 30:265274.

20. Relman, D. A., J. S. Loutit, T. M. Schmidt, S. Falkow, and L. S. Tompkins. 1990. The agent of bacillary angiomatosis: an approach to the identification of uncultured pathogens. N. Engl. J. Med. 323:1573-1580.

21. Saitou, N., and M. Nei. 1987. The neighbor-joining method: a new method for reconstructing phylogenetic trees. Mol. Biol. Evol. 4:406-425.

22. Sasser, M. 1990. Tracking a strain using the microbial identification system. MIDI Technical Note 102. Microbial ID, Inc., Newark, Del.

23. Schwartzman, W. A. 1992. Infections due to Rochalimaea: the expanding clinical spectrum. Clin. Infect. Dis. 15:893-902.

24. Smith, W. W., C. Wang, P. M. Gillevet, and W. Gilbert. 1992. Genetic data environment and the Harvard genome database. Genome mapping and sequencing. Cold Spring Harbor Laboratory, Cold Spring Harbor, N.Y.

25. Spach, D. H., K. P. Callis, D. S. Paauw, Y. B. Houze, F. D. Schoenknecht, D. F. Welch, H. Rosen, and D. J. Brenner. 1993. Endocarditis caused by Rochalimaea quintana in a patient infected with human immunodeficiency virus. J. Clin. Microbiol. 31:692-694.

26. Spach, D. H., A. S. Kanter, M. J. Dougherty, A. M. Larson, M. B. Coyle, D. J. Brenner, B. Swaminathan, G. M. Matar, D. F. Welch, R. K. Root, and W. E. Stamm. 1995. Bartonella (Rochalimaea) quintana bacteremia in inner-city patients with chronic alcoholism. N. Engl. J. Med. 332:424-428.

27. Stackebrandt, E., and O. Charfreitag. 1990. Partial 16S rRNA primary structure of five Actinomyces species: phylogenetic implications and development of an Actinomyces israelii specific oligonucleotide probe. J. Gen. Microbiol. 136:37-43.

28. Tappero, J. W., J. Mohle-Boetani, J. E. Koehler, B. Swaminathan, T. G. Berger, P. E. LeBoit, L. L. Smith, J. D. Wenger, R. W. Pinner, C. A. Kemper, and A. L. Reingold. 1993. The epidemiology of bacillary angiomatosis and bacillary peliosis. JAMA 269:770-775.

29. Wayne, L. G., D. J. Brenner, R. R. Colwell, P. A. D. Grimont, O. Kandler, M. I. Krichevsky, L. H. Moore, W. E. C. Moore, R. G. E. Murray, E. Stackebrandt, M. P. Starr, and H. G. Trüper. 1987. Report of the Ad Hoc Committee on Reconciliation of Approaches to Bacterial Systematics. Int. J. Syst. Bacteriol. 37:463-464.

30. Webster, G. F., C. J. Cockerell, and A. E. Friedman-Kien. 1992. The clinical spectrum of bacillary angiomatosis. Br. J. Dermatol. 126:535-541.

31. Weisburg, W. G., S. M. Barns, D. A. Pelletier, and D. J. Lane. 1991. 16S ribosomal DNA amplification for phylogenetic study. J. Bacteriol. 173:697703.

32. Weiss, E., and G. A. Dasch. 1982. Differential characteristics of strains of Rochalimaea: Rochalimaea vinsonii sp. nov., the Canadian vole agent. Int. J. Syst. Bacteriol. 32:305-314.

33. Weiss, E., G. A. Dasch, D. R. Woodman, and J. C. Williams. 1978. Vole agent identified as a strain of the trench fever rickettsia, Rochalimaea quintana. Infect. Immun. 19:1013-1020.

34. Weiss, E., and J. W. Moulder. 1984. Order 1. Rickettsiales Gieszczkiewicz $1939,25^{\text {AL }}$, p. $687-701$. In N. R. Krieg and J. G. Holt (ed.), Bergey's manual of systematic bacteriology, vol. 1. Williams and Wilkins, Baltimore.

35. Welch, D. F., D. A. Pickett, L. N. Slater, A. G. Steigerwalt, and D. J. Brenner. 1992. Rochalimaea henselae sp. nov., a cause of septicemia, bacillary angiomatosis, and parenchymal bacillary peliosis. J. Clin. Microbiol. 30:275-280. 